\title{
RECENT TRENDS IN WAGE GROWTH
}

\author{
Simon McLoughlin' \\ Strategy Group \\ Department of Labour
}

\begin{abstract}
Wage growth has risen since the beginning of the new millennium in response to an increasingly tight labour market. So far, however, most measures have shown relatively muted nominal growth in wages given that unemployment is at historic lows and reported staff shortages are at historic highs. Wages are vital to the performance of the labour market because they are an important incentive to attract people into industries and occupations where workers are in short supply, and make up a large proportion of income for people and of expenditure for firms. This paper examines recent wage trends in New Zealand to show that wage growth has been broadly appropriate in the current economic expansion. One of the key difficulties of looking at wage growth is the preponderance of different measures. This paper starts by outlining the various measures of wage growth and then these measures are used to analyse the link between wage growth and labour market conditions.
\end{abstract}

"Wealth - any income that is at least one hundred dollars more a year than the income of one's wife's sister's husband." Henry Louis Mencken

\section{Introduction}

Wages are vital to a well-performing labour market. They act as a beacon, attracting people into areas where workers are in short supply, and make up a large proportion of income for people and of expenditure for firms. ${ }^{2}$ The pace of wage growth has risen since 2000 in response to an increasingly tight labour market. But nominal growth in wages seems relatively muted, given that the recent economic expansion has delivered the lowest unemployment rate in almost 20 years and the highest reported staff shortages in more than 30 years.

Wages, encompassing all wages \& salaries, are the return on working or the "price of labour" and changes in wages are termed wage growth, as nominal average wages rarely fall and tend to rise over time. There are many wage growth measures and different ways to break them down. This paper examines relationships between selected measures and labour market conditions to show that wage growth has been broadly appropriate in the current economic expansion. Nevertheless, wage pressures have risen further in 2004 and wage growth may begin to rise after three years of being fairly stable. It remains to be seen how far wage growth rises because there is a lag between changes in labour market conditions and wages due to the infrequent nature of most wage negotiations.

\section{Wage Measures}

Workers usually know what is happening to their own wages but relativity is often more important than actual levels. Therefore, it is important to be able to compare wages. The one nationwide standard is the minimum wage, which was raised this year to $\$ 9.00$ for adults. There have been no other nationwide standards since general awards were abolished with the passing of the Employment Contracts Act (ECA) 1991, but there is a preponderance of different measures of wages and wage growth, each with their own advantages and disadvantages. The key difficulty in looking at wages proves to be this wide range of imperfect measures.

The two main sources of wage growth measures in New Zealand, the Labour Cost Index ( $\mathrm{LCl}$ ) and the Quarterly Employment Survey (QES), are both quarterly surveys of employers published by Statistics New Zealand.

The LCI started in the December 1992 quarter to replace the Prevailing Weekly Wage Rates Index (PWWRI), which was not needed after the ECA was passed. The LCI series examined here measures percentage change in all salary \& wage rates (including overtime) for a fixed quantity and quality of labour input, recording pay rises made for reasons such as matching market rates, keeping and attracting staff, and to reflect the cost of living. ${ }^{3}$ Service increments, merit promotions and movements relating to the performance of employees (eg irregular bonuses, commissions) and gains in qualifications or responsibility are not measured in the index because they reflect changes in labour quality. The $\mathrm{LCI}$ also excludes changes in the quantity of labour by surveying a set number of job positions, which are weighted using industry and occupation employment shares from the Census of Population \& Dwellings (firstly the 1991 Census and then the 2001 Census). ${ }^{4}$ This series is referred to in this paper as the adjusted LCI. 
From 1995, an experimental or unadjusted LCI is also available to supplement the adjusted series. The unadjusted LCI is the same as the adjusted version except it does not adjust for changes in the quality of labour. The unadjusted LCI includes all rises in salary \& ordinary time wage rates but still only measures wage growth for a fixed quantity of labour, so is unaffected by changes in the composition of employment. The difference between the adjusted and unadjusted LCI can be interpreted as growth in labour productivity (ie economic output per hour), although it reflects only the component due to labour quality changes and not the component from other sources such as more capital per worker (which is why the $\mathrm{LCl}$ is not used as a measure of unit labour costs).

By contrast, the QES measures changes in pay rates and changes in the composition of employment. ${ }^{5}$ Data are collected at the employer level and average hourly wages are calculated as total gross earnings divided by total paid hours, meaning the weights for the particular jobs within each firm and within each industry may vary. In terms of wage rates, the QES shows the average hourly wage as $\$ 20$ in the year to September 2004, with all but one industry at the 2-digit level between $\$ 10$ and $\$ 35$. The energy/mining-related industries topped the list with four of the five top paying sectors: oil \& gas extraction at $\$ 52$, services to mining at $\$ 33$, electricity \& gas supply at $\$ 29$ and metal ore mining at \$27. Several service sectors paid above-average wages, in particular, finance \& insurance, rail transport, government administration, education, health, and motion picture, radio \& television. Sectors with the lowest average hourly earnings were hospitality, personal services, food retailing, personal \& household good retailing, and textile, clothing, footwear \& leather manufacturing, which were all at or below $\$ 15$ in the September 2004 year. Gender and regional data are also available, eg Wellington City had high average hourly wages of \$29 for males and \$23 for females in mid-2004.

In terms of growth, the three measures from the LCI (adjusted and unadjusted) and QES generally move together but at different rates (Figure I). The adjusted $\mathrm{LCI}$ has the lowest annual wage growth over time. This is to be expected given the adjustment for labour quality changes. On the other hand, the inclusion of these changes in the QES and unadjusted LCI mean that these measures record higher wage growth. The unadjusted $\mathrm{LCl}$ almost always shows the highest growth in wage rates because it is not affected by the compositional changes that plague the QES measure. Therefore, in terms of gauging wage growth, the unadjusted LCI is the best of both worlds. ${ }^{6}$ Having said that, the relative stability of the adjusted $\mathrm{LCl}$ may merely reflect the stability of wages and consumer price inflation over the past 12 years, and the QES measure does reflect the true wage bill of employers. However, a wider measure of wage pressures is still needed. For now, this is the unadjusted $\mathrm{LCl}$, despite it being experimental (as the survey was designed to measure adjusted wage growth) and only available since 1995. The analysis below will examine all three measures, as each is appropriate in certain circumstances. For example, the LCI has a full industry coverage that the QES does not, the adjusted LCI can look at occupations and has a longer time series than the unadjusted LCI, while the QES provides wage rate data.

There are other ways to analyse wage growth and wage pressures. Some come from breaking down the LCI in different ways, eg proportion of wage increases that are over $5 \%$, and the average rise of those wage rates that

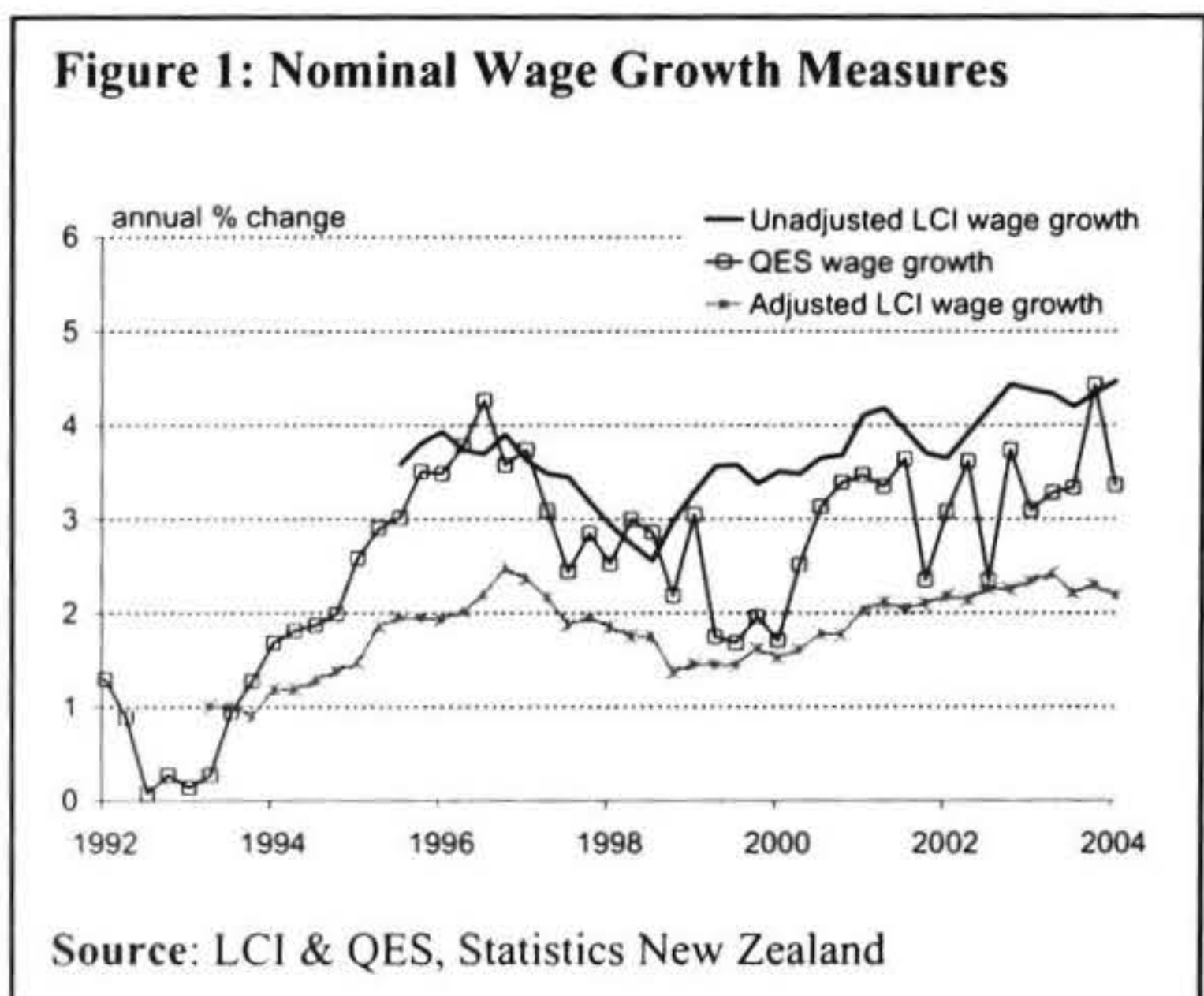

changed. Compensation of employees is a broad measure of wages and comes from the National Accounts using AES and tax information. A lot of other Statistics New Zealand data adequately cover wages (directly or indirectly), but not wage growth. The Census of Population \& Dwellings provides detailed information on annual incomes ${ }^{7}$, eg at March 2001 (Figure 2) medical and law professionals dominated the top 12 of 562 occupations. These figures are, however, more than three and a half years old, as the Census is only carried out once every 5 years.

The New Zealand Income Survey (NZIS) is more up-todate and can break down the different sources of income, including wages \& salaries and earnings from selfemployment. However, the NZIS is an annual supplement to the Household Labour Force Survey (HLFS), not quarterly, cannot provide much detail as it is

\begin{tabular}{|c|c|c|}
\hline \multicolumn{3}{|c|}{ Figure 2: Average Income by Occupation } \\
\hline Ranking & Selected occupational titles & Annual income (\$) \\
\hline 1 & Surgeon & 121,969 \\
\hline 2 & Anaesthetist & 121,320 \\
\hline 3 & Judge & 107,228 \\
\hline 4 & Member of Parliament & 105,558 \\
\hline 5 & Gynaecologist \& Obstetrician & 103,765 \\
\hline 7 & Radiologist, Radiation Oncologist & 93,698 \\
\hline 10 & General Practitioner & 83,066 \\
\hline 11 & Economist & 79,570 \\
\hline 12 & Barrister \& Solicitor & 78,959 \\
\hline 522 & Sales Assistant & 19,206 \\
\hline 562 & Checkout Operator & 8,854 \\
\hline Average & All employment & 32,826 \\
\hline
\end{tabular}


a survey, and collects responses from individuals, which may be less reliable than responses from employers. Compared to the QES, the NZIS is not able to provide reliable rates of wage growth but can provide similar types of information on wage rates and has a full coverage of industries that the QES lacks. The average hourly wage in the NZIS of \$18.24 in the June 2004 quarter is below the $\$ 20$ in the QES because of the inclusion of some lower-paid sectors and because the NZIS measures average wages per person, rather than per job as in the QES (people can have more than one job). The NZIS can be used for much more complex wage analysis across industries and can also look at occupations. The distribution of wage rates can be examined, with the average (ie mean) above the median (ie middle) of $\$ 15.34$ at June 2004 as the distribution of hourly wages is skewed to the right (Figure 3 uses 2003 data). Secondly, rough estimates can be made of the average starting wage and typical age of maximum wage across occupational groups, as well as what effect gender, different qualifications, birthplace etc can have on wages. For example, the typical age of peak earnings seems to vary from 42 years for drivers \& mobile machinery operators to 67 years for legislators \& administrators (eg CEOs, MPs). Average weekly wages can also be computed, and stood at $\$ 817$ for a full-time worker and $\$ 245$ for a part-time worker at June 2004. There are various other Statistics New Zealand wage measures. Some of these have been discontinued and others are still being worked on, such as the Linked Employer-Employee Data (LEED) project and the Survey of Family Income \& Employment (SoFIE).

Apart from Statistics New Zealand, other sources of wage information include databases of employment agreements at the Department of Labour (DoL) and Victoria University of Wellington, the Wage \& Salary Survey from the Employers \& Manufacturers Association, and the Hays Salary Survey. DoL also receives wage data

Figure 3: Distribution of Hourly Wages

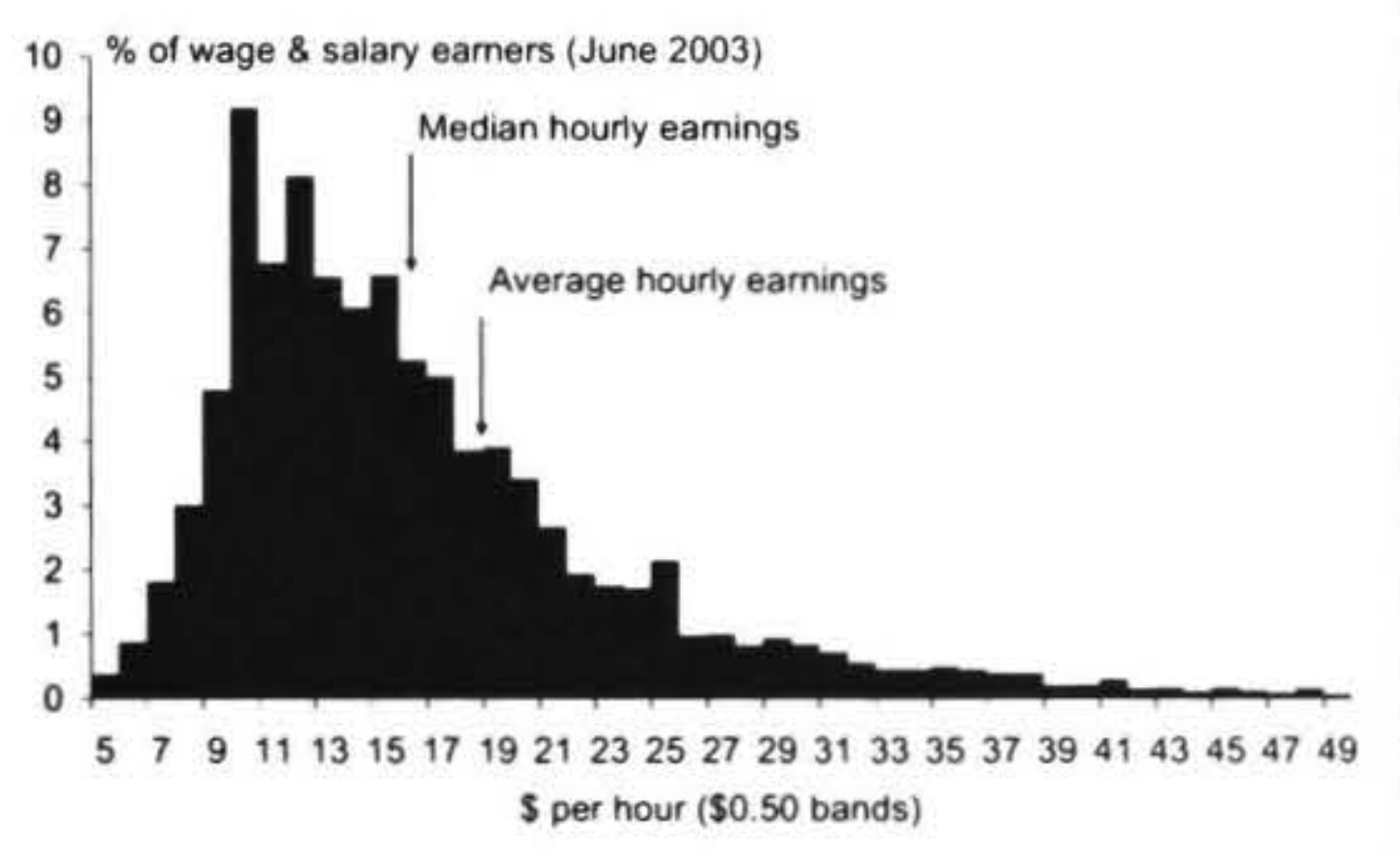

Source: NZIS, Statistics New Zealand, DoL calculations

through the Job Vacancy Monitoring Programme (JVMP). Lastly, a range of remuneration surveys are conducted for specific industries and occupations (eg accounting, engineering, hospitality) and within organisations, which are all crucial for wage setting.

\section{Trends in Nominal Wage Growth}

Wage growth has been higher over the last three years compared to the previous three years but has been broadly stable since 2001 .

The measure we chose as the best gauge of wage growth, the unadjusted LCI, shows that annual wage growth for a fixed quantity of labour rose from $2.6 \%$ in 1999 to $4.5 \%$ at September 2004, the strongest growth since it began in 1995. The private sector series shows higher growth, up to $4.7 \%$ in the year to September 2004 , although it had also reached this high rate of growth in mid-2003.

On the other hand, the adjusted LCI gives growth in pay rates for a fixed quality and quantity of labour of $2.2 \%$ in the year to September 2004, down from a $61 / 2$-year high of $2.4 \%$ in the year to December 2003, and well below the peak of $2.5 \%$ in the year to June 1997 (Figure I). Basically, the LCI shows the average person in work this time last year had an increase in their wages or salary of $4.5 \%$ over the year, with $2.2 \%$ of this due to an adjustment to reflect the market (the adjusted LCI) and $2.3 \%$ due to an improvement in their performance. If the difference between the two LCIs is labour productivity growth, then productivity growth rose to $2.3 \%$ in the year to September 2004 compared to $2.0 \%$ in the previous year and $0.8 \%$ in year to March 1999 . The LCI also shows that $14 \%$ of salary \& wage rates that changed in the past year were increases of more than $5 \%$, the highest figure on record. QES average wage growth has been affected

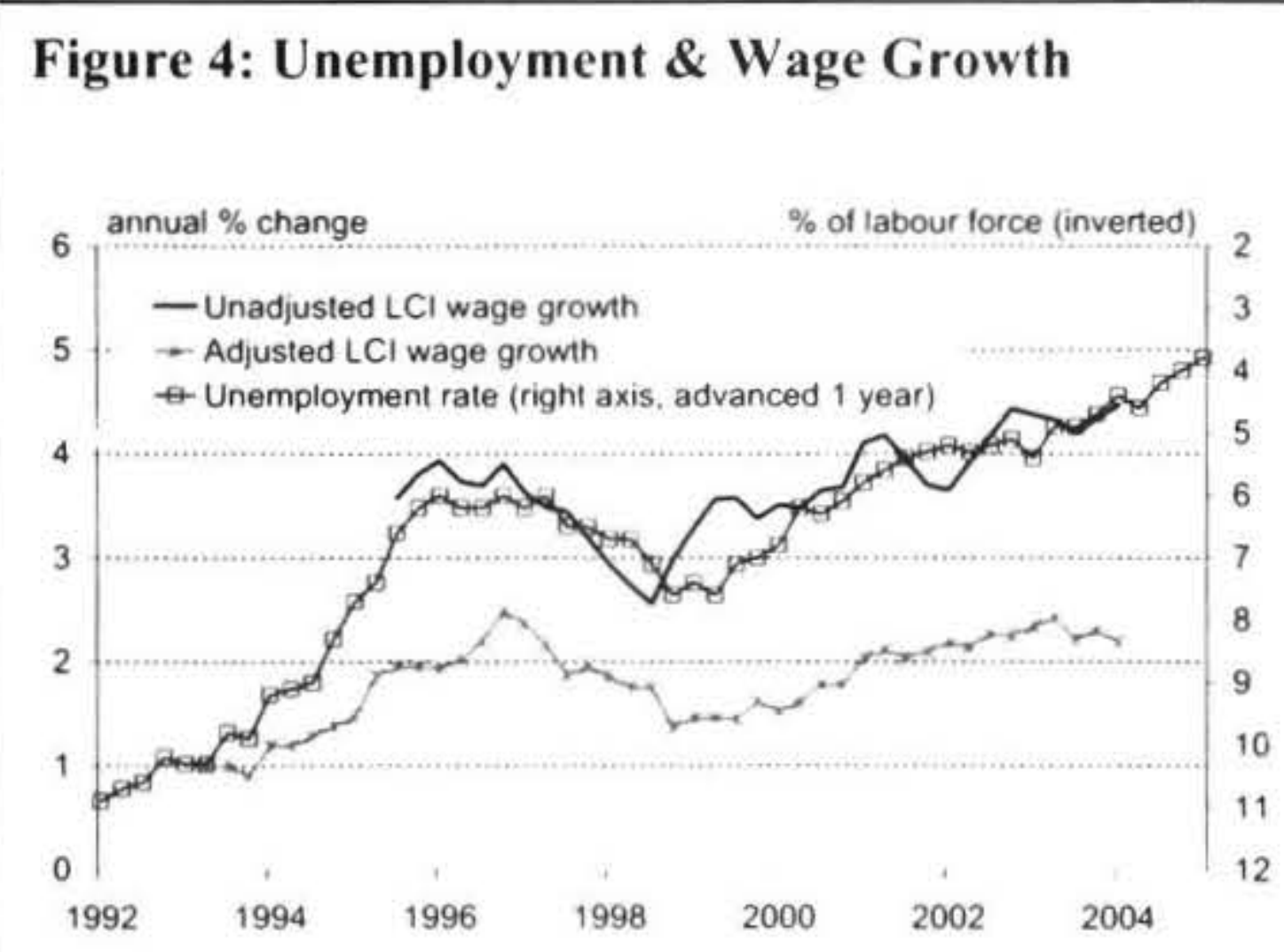

Source: HLFS, LCI, Statistics New Zealand

by compositional changes and therefore, at $3.4 \%$ in the year to September 2004, is not as high as the unadjusted LCI.

These three wage growth measures are much higher than during the 1998-2000 period, but have not really moved up in the last three years. The unadjusted LCI is the highest since it began but not much above the $4.4 \%$ rise in the year to September 2003 or the $4.1 \%$ rise in the year to September 2001 .

Other measures, including compensation of employees, the average hourly earnings from the NZIS, and the DoL collective agreement database, also show that wage 
growth was relatively high over the last three years, but has failed to materially rise over the course of this period. On the face of it, this seems surprising given the New Zealand labour market has improved significantly after emerging from the recession of 1997/98: the unemployment rate fell from $7.6 \%$ at December 1998 to $6.2 \%$ at December 1999 and then more gradually to an 18 -year low of $3.8 \%$ in the September 2004 quarter; labour demand has surged with high job and hours growth; duration in unemployment and underemployment are low; and employment has risen and unemployment has fallen considerably across most groups. Labour supply growth has been strong due to record levels of annual net migration and a high labour force participation rate, but growth in labour demand has been much stronger. Thus firms are having a lot of difficulty finding the staff they need, with staff shortage indicators at historic highs.

A more measured look at the relationship between wage growth and the unemployment rate shows that, for the LCI measures, wage growth has risen broadly in line with the fall in the unemployment rate since 1999 (Figure 4). The adjusted $\mathrm{LCl}$ provides the longer time series of the two wage indexes and shows that growth rose quickly in response to the sharp fall in unemployment in 1999 and 2000 and then steadied as unemployment steadied in 2001/02. There is a lag of around one year as the infrequent nature of wage negotiations means that wage growth responds to the unemployment rate one year earlier. It seems that the unadjusted LCI responded more quickly than the adjusted LCl to the lower unemployment of $1999 / 2000$ but this relationship is difficult to examine due to the short time series. Both the $\mathrm{LCl}$ measures seem to show nominal wage growth broadly in-line with the level of the unemployment rate, and the further fall in unemployment in the last year points to a rise in both measures towards $2.5 \%$ for the adjusted LCI and $4.7 \%$ for the unadjusted LCI by late-2005.

Since 1992, the relationship between QES wage growth and the unemployment rate also suggests that wage growth lags unemployment by around one year. This lag points to QES wage growth of around $4 \%$ in the past year versus actual growth of $3.4 \%$. However, composition changes make the QES a volatile series on a quarterly basis, with annual wage growth falling from a 131/2-year high of $4.4 \%$ at June 2004 to $3.4 \%$ at September 2004. Using an annual average percentage change to smooth these movements, we get a rise of $3.6 \%$ in the year to September 2004, still well short of $4 \%$. The most recent unemployment rate of $3.8 \%$ is suggestive of a forthcoming rise in QES wage growth.

The QES measure, being sensitive to compositional changes, is the least reliable of the three measures examined. An obvious explanation may be that lowpaying industries have experienced stronger growth in hours paid, thereby increasing their influence and dampening average wage growth. While growth in the quantity of jobs cannot be questioned at $2 \frac{1}{2-3} \%$ per annum in the last four years (versus an OECD average of $0.6 \%$ and Australia at $1.9 \%$ ), a question surrounds the quality of job growth. Looking at the QES, most growth in labour input (using hours paid) over the last four years came from industries such as retail trade, property \& business services, health \& community services, manufacturing, and construction. Apart from property \& business services, these sectors were in the bottom half of the industries ranked by average hourly wages in the year to September 2000 so almost two thirds $(64 \%)$ of growth in hours paid were in these lower-paid sectors. However, looking at a finer level of industry detail reduces this figure to $51 \%$ : eg strong growth in health \& community services was mostly in the above-average paid sub-sector of health services. The equivalent figure for the four years to September 1996 (which had a very similar rise in hours paid of $16 \%$ versus $14 \%$ for the four years to September 2004) was $71 \%$ at the aggregate 1-digit industry level and $68 \%$ at the finer 2-digit level. Drawing people from unemployment into work is expected to lower the average level of productivity (and thus wages). The recent expansion in labour input has been driven less by lower-paid jobs than the previous expansion, perhaps because the fall in the unemployment rate has been smaller (roughly from $10 \%$ to $6 \%$ for 1992-1996 and from $7 \%$ to $5 \%$ for $1998-2003$ ), but it has still had an impact. There may be other composition changes that have lowered QES wage growth, such as high job growth for females and changes within industries and firms.

Another possible reason why annual wage growth has not risen strongly over the last three years may be that unemployment has fallen more gradually since 2001 after a sharp fall in $1999 / 2000$. The $1.5 \%$ point fall from 1998 to 2000 may have placed far greater pressure on wage growth than the $0.6 \%$ point fall from 2001 to 2003, with the further fall to $3.8 \%$ in September 2004 yet to have an impact. Changes in unemployment - rather than a low level of unemployment per se - may indeed play an important role in wage negotiations. Falling unemployment reduces the chance of redundancies and reduces the proportion of short-term unemployed, who are more likely to compete with existing workers (consistent with an "insider-outsider" model). This relationship works well for the QES measure and may partly explain why all wage growth measures rose so suddenly in 2000/01 and then stabilised.

The level of staff shortages as reported by firms also has a strong relationship with growth in wages. This is not surprising as staff shortage indicators move closely with unemployment. The two best staff shortage indicators are from the Quarterly Survey of Business Opinion (QSBO): the difficulty of finding skilled/specialist staff and the difficulty of finding unskilled/semi-skilled staff. At the moment, both are very high but it is the latter that is the highest on an historical basis. In the September 2004 quarter, a net $34 \%$ of firms reported more difficulty finding unskilled/semi-skilled staff, the highest figure in the 30 -year history of the series, and a net $54 \%$ had more difficulty finding skilled/specialist staff, lower than figures from the mid-1990s and mid-1980s. The relative difficulty of finding unskilled/semi-skilled staff can be attributed to the sharp fall in the number of unemployed people, who tend to have lower-than-average skills and who are let go first during a downturn, as firms tend to hoard skilled labour. Wage growth has risen 
appropriately as shown in Figures 5 and $6 .^{8}$ Weighted by employment, the wage growth of skilled/specialist occupations rose to $2.5 \%$ in the year to September 2003 but fell back to $2.0 \%$ in the year to September 2004. By contrast, the wage growth of unskilled/semi-skilled occupations rose to $2.5 \%$ in the year to September 2004 from $2.2 \%$ in the year to September 2003. Both indicators track the respective difficulties of finding staff. The JVMP shows job vacancies rising more for lowerskilled positions since late-2002, further confirming that demand is relatively high for lower-skilled staff. The LCI shows that the occupations that are most in shortage are tending to have the strongest wage growth, including building trades workers, elementary workers, plant \& machinery workers, and health professionals.

The two labour market indicators that have not been particularly rosy in the current economic expansion are growth in real wages and labour productivity. As the next section shows, the lack of strength in these indicators is likely to have been related.

\section{Figure 5: Skilled Staff \& Wage Growth}

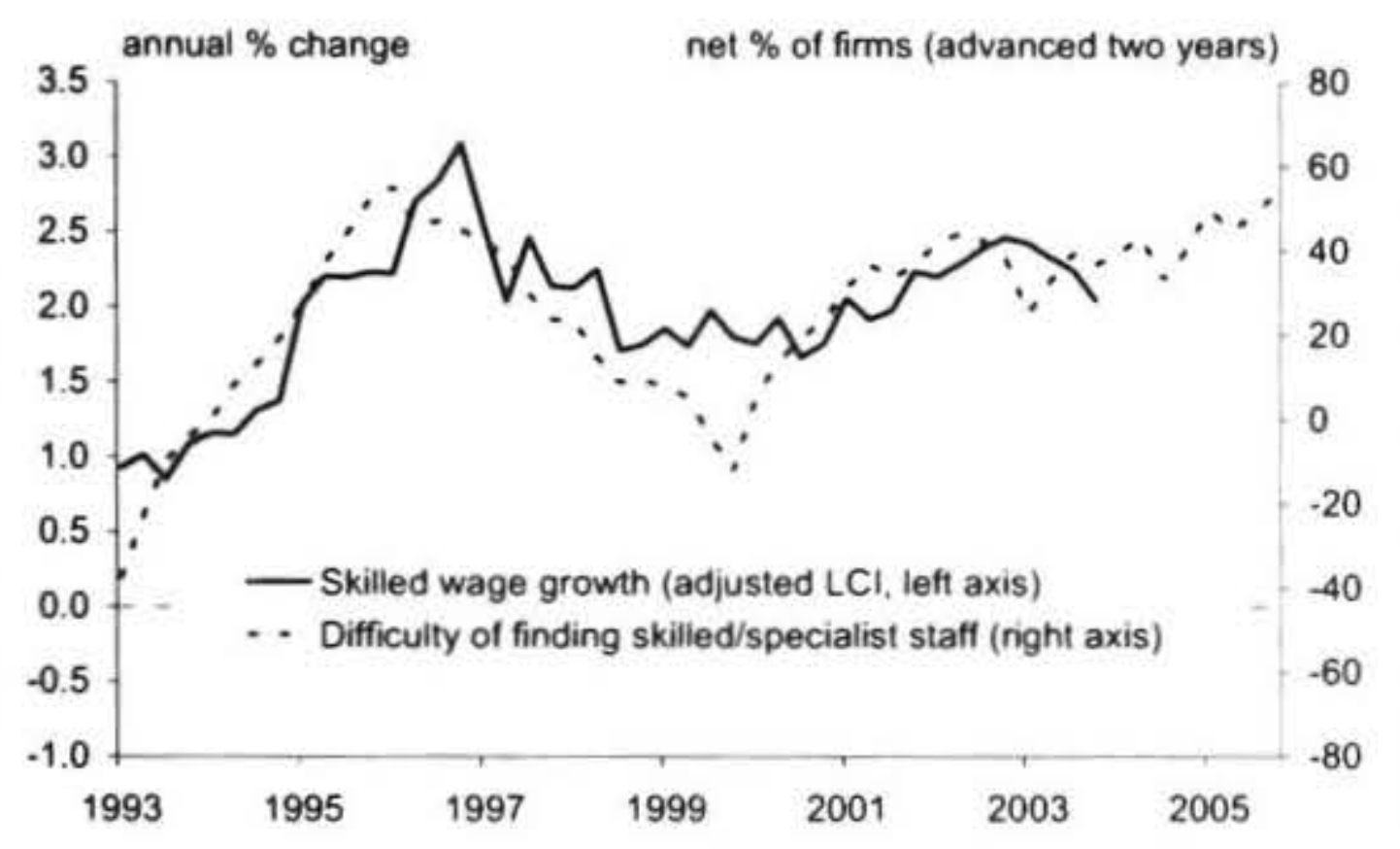

Source: LCI, Statistics New Zealand; QSBO, NZIER; DoL

\section{Figure 6: Unskilled Staff \& Wage Growth}

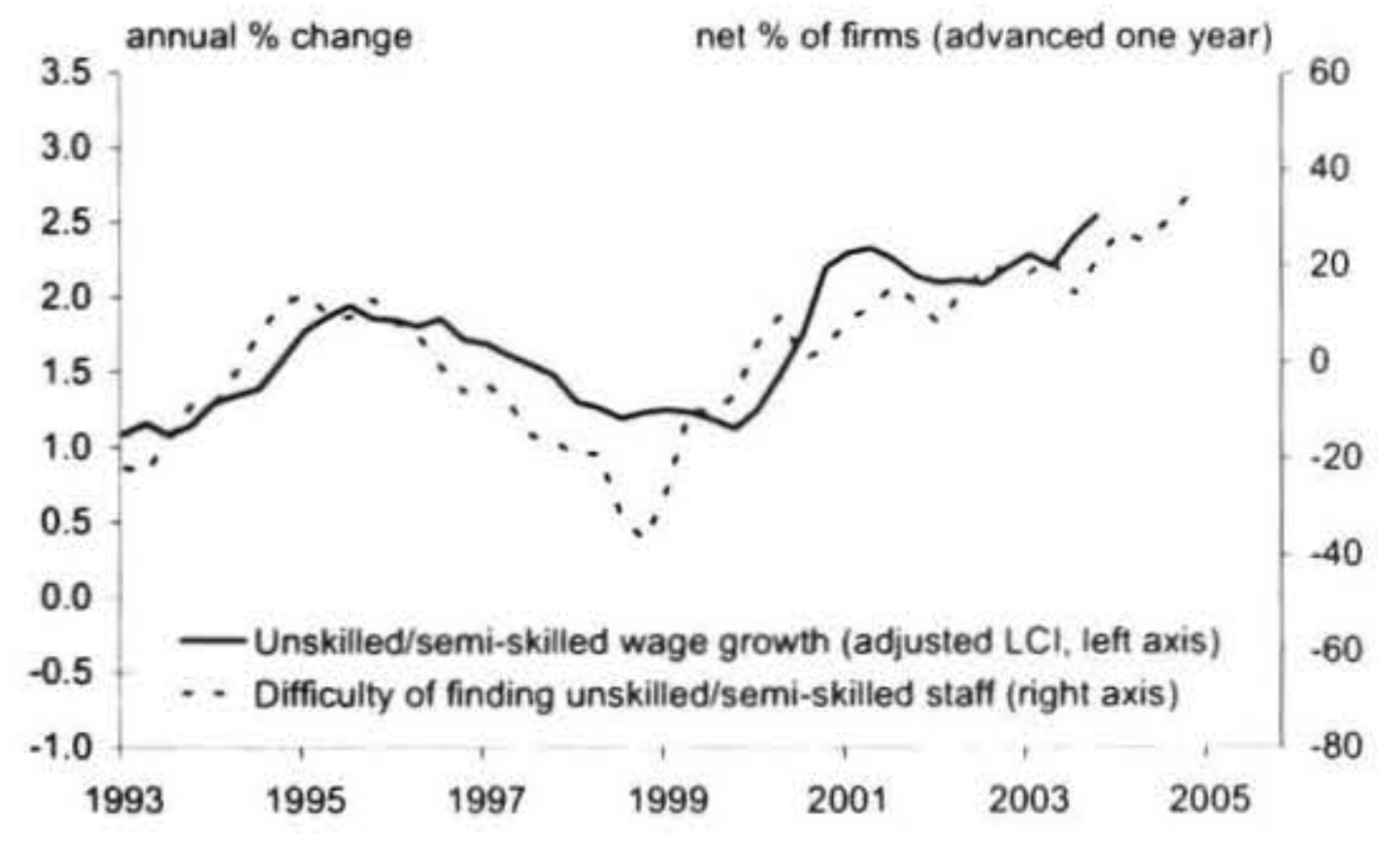

Source: LCI, Statistics New Zealand; QSBO, NZIER; DoL

\section{Trends in Real Wage Growth}

Nominal wage growth (not adjusted for price changes) is worth looking at because of the clear inverse relationship with unemployment in the low inflation environment of the mid-1990s and early-2000s. However, real wage growth (adjusted for changes in prices) is more important. Workers take account of price changes to protect and improve their purchasing power and standard of living. With a lower unemployment rate and thus more bargaining power, real wage growth will tend to rise. Other factors that will affect real wage growth include changes in labour productivity, taxes, union density, terms of trade and legislation. The same factors will also affect real wage growth from a firm's point of view. Real wages are paramount to firms' recruitment decisions as higher real wages discourage hiring if labour productivity has not risen to compensate. Using real wage growth is also the only meaningful way to compare across longer time periods or across nations. This point is illustrated well by going back one century with the QES and its predecessors: nominal wage growth is as much as $20 \%$ per annum in the early-1980s and rarely falls on an annual basis (notably in the great depression).

Real wage growth for a worker can best be calculated by deflating one of our three measures by the Consumers Price Index (CPI). QES real wage growth is much lower than nominal growth over time and declines on occasion, with some spikes as worker's react to high CPI movements or vice versa. Nominal wage growth is affected by CPI changes about a year earlier, a relationship cemented in the early-1990s after a period when wages seemed to lead price changes. A simple explanation is that workers are using inflation from the iast year as the expected inflation for the year ahead when negotiating wages, with some adjustment for past errors. CPI inflation averaged $2.7 \%$ per annum between 2000 and 2002 so was another factor underpinning nominal wage growth from 2001 to 2003 . However, at just $1.5 \%$ in the year to September 2003, CPI inflation may be acting to soften nominal wage growth in 2004. CPI inflation has since risen to $2.5 \%$ in the year to September 2004 and is expected to rise further in 2005.

The addition of the CPI means there are longer lags for real wage growth in response to labour market conditions than for nominal wage growth. It takes two years for a lower unemployment rate to push real wage growth up, as the fall in the unemployment rate in 1999 saw real wage growth (as measured in the adjusted LCI) rise in 2001. Thus the real wage growth of the past year is responding to the unemployment rate of $2002,5-6 \%$, rather than that of 2003 of under $5 \%$ (or $3.8 \%$ now).

Real wage growth has been solid over the last three years but, like nominal growth, has not shown a strong upward trend (Figure 7). Using the unadjusted LCI, real wages rose by $1.9 \%$ per annum on average between the years to September 2001 and 2004, while growth in the QES real measure was $1.1 \%$ per annum. These rates are similar to growth in the previous six years. Compared to the previous two decades, these are solid gains in real wages. They are also in-line with what has happened across the 
OECD. For the manufacturing sector, New Zealand's real wage growth (QES) of $1.0 \%$ per annum in the five and ten years to June 2004 is identical to the "Major seven" OECD countries and places New Zealand in the middle of those nations with comparable data.

Real wages from a firm's point of view can be measured by deflating QES average hourly earnings by the Producer Price Index (PPI) output series. This real wage series rose to around $3 \%$ per annum in the last three years after falling sharply in 2000 due to high growth in producer prices caused by the very low value of the New Zealand dollar (which raises prices of imports). Firms are more interested in what this real wage produces, so real unit labour costs tell us what is happening to the real labour cost per unit of output. Real unit labour costs divide real wages from a firms' perspective by labour productivity (output per hour). Moderate gains in labour productivity in recent years mean real unit labour costs have remained fairly steady.

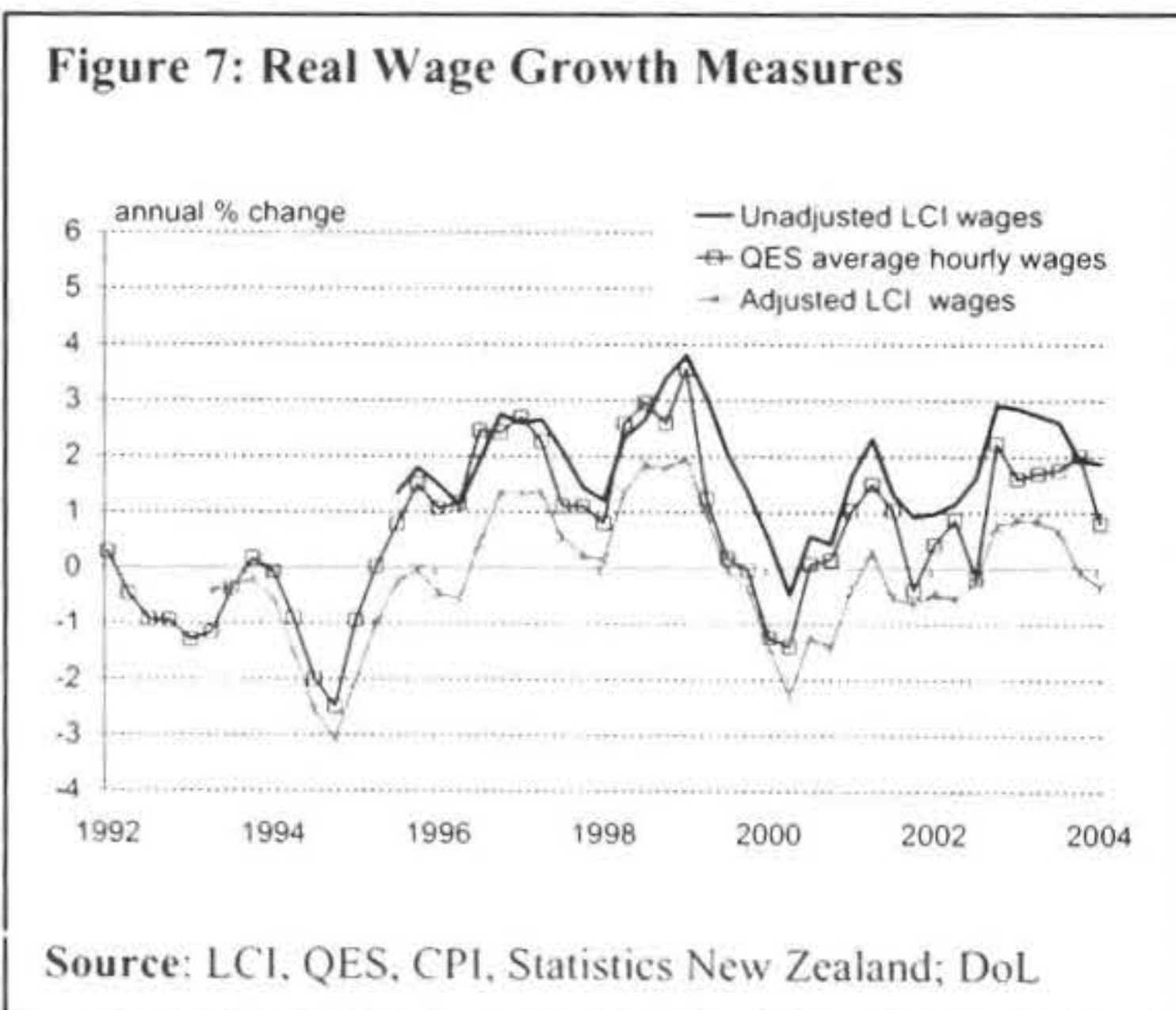

Long-term, there is evidence that real wage gains between 1989 and 2004 were matched by labour productivity gains (using GDP divided by HLFS hours worked) and terms of trade movements (Figure 8). Growth in labour productivity has been moderate to solid (not weak and not strong) in recent years at around $1-1 \frac{1}{2} \%$ per year and this has been reflected in higher real wages. The same analysis can be done by industry to see whether real wages have adjusted appropriately to changes in demand and labour productivity in each industry. This tentative analysis has many caveats - including concerns over the data and the choice of starting point - but does suggest that wages have functioned well by rising in sectors that have improved their labour productivity performances and/or have experienced improvements in their terms of trade over the past 15 years. For example, the industries with the strongest real wage growth (electricity, gas \& water, mining, and finance $\&$ insurance) had some of the strongest growth in labour productivity, the sector with the weakest real wage growth (accommodation, cafes \& restaurants) had a poor productivity performance, and the sector with the next worst real wage growth (forestry \& mining) had the most adverse change in the terms of trade. There were only two main exceptions: communications had exceptionally strong labour productivity growth that more than offset a worsening terms of trade, but still had low growth in real wages; and property \& business services had strong growth in real wages that was not met by an improved productivity or terms of trade performance. Overall though, it seems that real wage growth has been in-line with growth in labour productivity. Recent growth in real wages is not very different from real wage growth in the mid-1990s, which may be fitting given that growth in the productivity of the workforce has not improved in this time. Thus there seems to have been no shift or only a small shift in economic/bargaining power to workers in the recent expansion (eg the labour share of GDP has been fairly steady) as would be expected if there has been little or no differences between growth in labour productivity and real wages.

\section{Figure 8: Real Wage Growth \& Productivity}

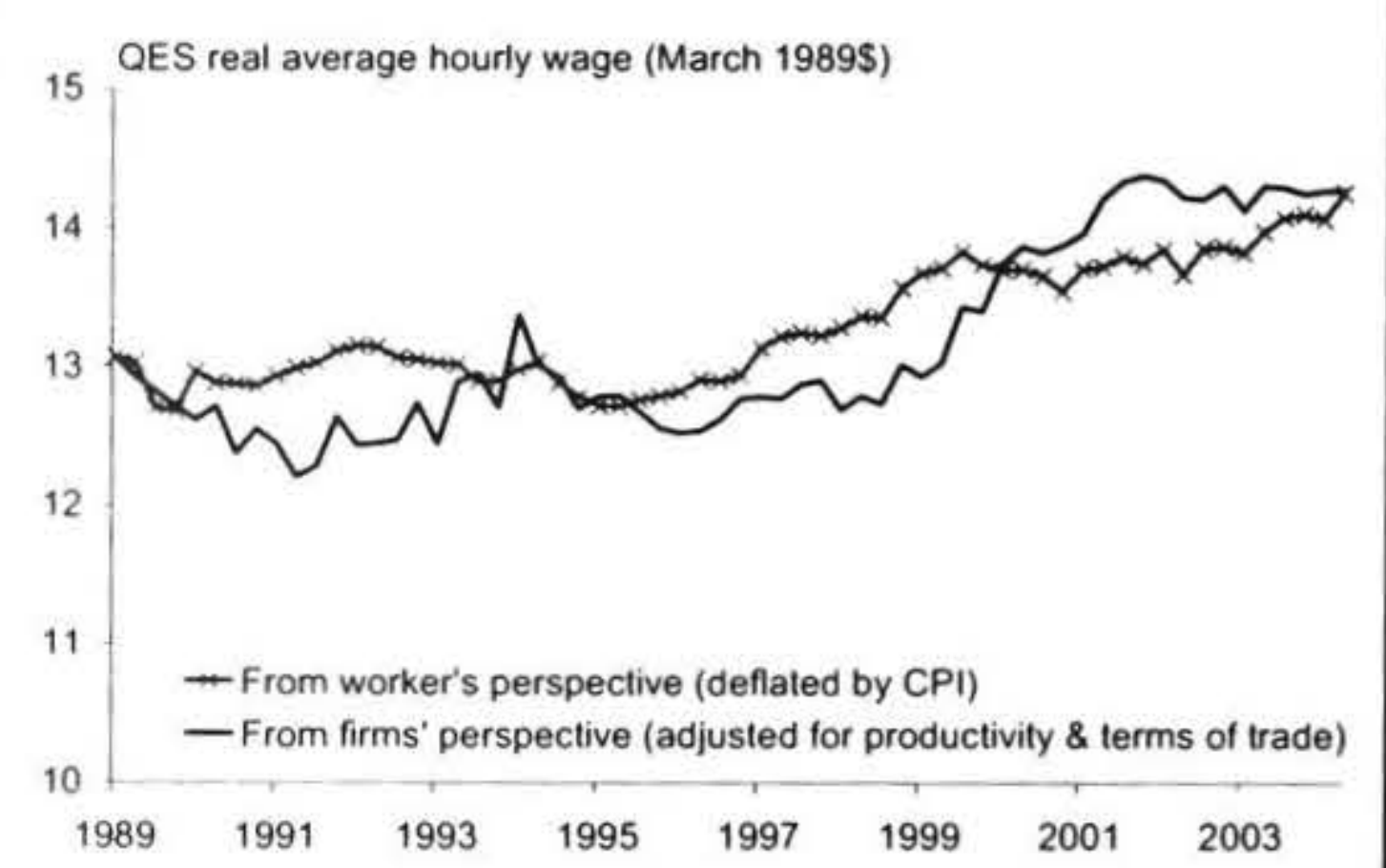

Source: QES, GDP, HLFS, CPI, PPI; DoL calculations

\section{Discussion}

It has been widely suggested that wage growth has not been as strong as might be expected given the strong cyclical position of the economy, low unemployment, and introduction of the Employment Relations Act (ERA) 2000. There are a range of factors that may have dampened recent growth in wages: business confidence has been very low on average since 2000 and may have caused firms to hesitate in lifting wages; new legislation has given gains to workers such as more benefits for those who work on holidays or on the minimum wage; high job security and rising hours of work may have lessened the need for higher hourly rates of pay; high migratory inflows and record high labour force participation rates may have placed downward pressure on wages; and there may have been greater use of nonwage benefits. Raising wages is a response to solve skill shortages, but it is not the only one. Strategies include: making more use of non-wage benefits, including bonuses, promotions, vouchers and performance pay'; providing a better work environment (open door policies, lifting morale, challenging work); and greater use of training. 
However, this paper suggests that wage pressures are relatively high: the unadjusted $\mathrm{LCI}$ is running at its fastest pace since it started in 1995; the relationship between wage growth and the unemployment rate remains remarkably consistent; moderate growth in labour productivity has been met by moderate growth in real wages; the industries with the strongest growth in demand and/or labour productivity and the occupations most in shortage (trades, some professionals) have tended to experience the strongest wage growth; and a record high $14 \%$ of settlements in the September 2004 quarter were for wage rises of more than $5 \%$.

Further, the lagged relationships between wage growth and labour market conditions suggests that wage growth has yet to peak and will rise in the year or two ahead as the current unemployment rate of $3.8 \%$ and high staff shortages will act to boost wage growth. This is likely to occur even if there is a slowdown in economic growth forecast in the latest Consensus Forecasts to fall from $4.4 \%$ in the June 2004 year to $2.3 \%$ by the March 2006 year. This could create a scenario similar to that which occurred in 1997, when wage growth was very high as a delayed response to the labour market peak a year earlier, even though the economy entered recession in late-1997.

The past year has seen a rise in wage growth for unskilled positions offset a slight fall for higher-skilled positions that was partly caused by lower growth for teaching professionals after their large increase in 2003. There may be some further pressure in the public sector, where wage growth has been stronger than in the private sector for the past four years and may continue due to shortages of staff in government-dominated sectors such as education and health. But overall there is little reason to expect wage growth to deviate from the relationships with unemployment and productivity described above. Firms seem to be giving wage increases only when earned, consistent with the unadjusted $\mathrm{LCI}$ being the measure currently running at a record high annual pace of $4.5 \%$ while the adjusted LCI is down to $2.2 \%$. Nominal and real wage growth are expected to rise in the next two years, but exceptionally high wage growth is not expected without a corresponding lift in labour productivity, continuing the apparent trend of the last 10 to 15 years. Unfortunately, we will have to wait at least two years to conclude whether wage growth has been appropriate in the current economic expansion.

This paper raises several areas for future research including work on better measures of wage growth and non-wage benefits, wage dispersion, earnings of all employed people, and the link between inflation and wages. Finally, there is scope for more work on the relationship between labour productivity and real wages, including the concept of efficiency wages. The above analysis focused on real wages responding to labour productivity, whereas the efficiency wage theory says that higher real wages can lead to higher productivity:

"I don't pay good wages because I have a lot of money; I have a lot of money because I pay good wages.", Robert Bosch.

\section{Notes}

1. Simon McLoughlin is an economist at the Department of Labour. The views represented in this paper are the author's own and should not be taken to represent the views of the Department of Labour.

2. Wages \& salaries account for $63 \%$ of the average person's total income according to the New Zealand Income Survey (NZIS), up to $72 \%$ for those in paid work, and approximately $15 \%$ of an employer's production costs according to the Annual Enterprise Survey (AES), up to $62 \%$ for those in education.

3. The LCI records wage rates and uses these to calculate the published index. However, the wage rates themselves are not published because the sample is not randomly selected, is too small, and was not designed to accurately measure wage rates.

4. A non-wage LCI is also available but offers little useful information on the uptake and growth in nonwage benefits. For example, it fell $0.6 \%$ in the June 2004 year due to fewer statutory holidays in that year (ANZAC Day was on the weekend), a fall in motor vehicle prices and a fall in loan repayments as there was a lower interest rate charge. The QES picks up some non-wage benefits (such as annual and statutory holidays) if they fall in the survey week, which is the payweek ending on, or immediately before, the $20^{\text {th }}$ of the middle month of the quarter (Note: the LCI is for the pay period when the $15^{\text {th }}$ of the middle month of the quarter falls).

5. The QES started in 1980 when it replaced the Half Yearly Employment Survey (HYES), which was published by the Department of Labour, as was the QES, until 1988. The QES does not have full industry coverage (eg excludes agriculture, hunting, fishing, private households employing staff).

6. The adjusted LCI shows too little variation (annual growth has varied between 1.4 and $2.5 \%$ since 1996) and the QES shows too much (1.7 and $4.4 \%$ in the same time). Also, the QES can record falls in average hourly earnings (eg average wages fell $0.3 \%$ in the June 2002 quarter, private sector average wages fell $0.3 \%$ in the September 2004 quarter), even if no individual pay rates fell. The unadjusted LCI is less volatile than the QES (2.6-4.5\% since 1996).

7. There is no wage \& salary information and annual income bands are used. Sources of personal income are recorded but with only one value for total personal income. There are small differences in time periods for income (year to 31 March 2001) and occupation (week to 4 March 2001) and only the occupation of main job is recorded.

8. There is no definition of skilled/specialist or unskilled/semi-skilled in the QSBO, but the assumption is made that the former refers to the top three occupations (managers, professionals \& technicians) and the latter takes the remainder, except 
agriculture \& fishery workers, which cuts across the skill spectrum, and the primary sector is not in the QSBO. The inclusion of trades in semi-skilled instead of skilled makes little difference to results.

9. Firms may already be responding with alternative strategies but these data are limited. A survey of 1,000 workers in New Zealand (2,400 in Australia) by recruitment agency Kelly Services estimated that $32 \%$ of New Zealand workers are on performance pay compared to only $12 \%$ of Australia workers.

\section{References}

Briggs, P. (2003), Looking at the numbers: a view of New Zealand's economic history, NZIER. www.nzier.org.nz/SITE Default/SITE Publicatio ns/research_monographs.asp\#0-2

Dixon, S. (1995), Inter-industry Wage Structure 1974 1994, Labour Market Bulletin 1995:1, DoL. www.dol.govt.nz/PDFs/lmb951c.pdf

Employers \& Manufacturers Association, Wage \& Salary Survey. www.nzsalarysurvey.org.nz

Employment Relations Service, ERA Info: The Report on Employment Relations in New Zealand, DoL. www.ers.govt.nz/publications/era_info.html

Grimmond, D. (2002), A Report Card on the New Zealand Labour Market: Improving, Could do Better. Proceedings of the $10^{\text {th }}$ Labour, Employment and Work conference. www.dol.govt.nz/PDFs/report-card.pdf

Grimmond, D. (2004), Unpublished work on New Zealand Income Survey.

Gobbi, M. (1997), Some Notes on Determining Real Wage Movements, Labour Market Bulletin. DoL. www.dol.govt.nz/PDFs/Imb971d.pdf

Harbridge, R., Thickett, G. and Kiely, P. (2002), Employment Agreements: Bargaining Trends \& Employment Law Update.
Hays (2004), Hays Salary Survey 2004. www.hays.com. au/salary/index.asp

Job Vacancy Monitoring Programme (2004), Job Vacancy Monitor, DoL www.dol.govt.nz/publications/jvm/job-admonthly-report.asp

Kelly Services (2004), Australia and New Zealand survey of workplaces.

www.kellyservices.com.au/main.cfm?site_id=1\&it em_id $=2396$

National Bank (2004). Business Outlook. www.nbnz.co.nz/economics/outlook/NBNZ_Busin ess_Outlook_Data.xls

New Zealand Institute of Economic Research (2004), Consensus Forecasts - September 2004. www.nzier.org.nz/SITE_Default/SITE_Publicatio $\mathrm{ns} / \mathrm{x}$-files/7724.pdf

New Zealand Institute of Economic Research (2004). Quarterly Survey of Business Opinion

OECD (2000), The Concept, Policy Use and Measurement of Structural Unemployment www.oecd.org/dataoecd/14/51/1885410.pdf

Reserve Bank of New Zealand (2004), Monetary Policy Statement - September 2004 www.rbnz.govt.nz/monpol/statements/sep04.pdf

Statistics New Zealand. www.stats.govt.nz

Statistics New Zealand (2004), Christchurch Quarterly Review - June 2004.

www.ccc.govt.nz/Reports/StatisticsQuarterlyRevie w/2004June.pdf

Whiteford, Andrew, Job Vacancy Monitoring Programme: An Overview, Proceedings of the $11^{\text {th }}$ Labour, Employment and Work conference. 